\title{
TWO TYPES OF ASTROCYTES IN CULTURES OF DEVELOPING RAT WHITE MATTER: DIFFERENCES IN MORPHOLOGY, SURFACE GANGLIOSIDES, AND GROWTH CHARACTERISTICS ${ }^{1}$
}

\author{
MARTIN C. RAFF, ${ }^{*, 2}$ ERIKA R. ABNEY,* JIM COHEN, ${ }^{*}$ RONALD LINDSAY, $\ddagger$ AND MARK NOBLE*, \\ * Medical Research Council Neuroimmunology Project, Department of Zoology, University College London, London WC1E \\ $6 B T$ and $\ddagger$ National Institute for Medical Research, Mill Hill, London NW7 1AA, England
}

Received October 13, 1982; Revised December 27, 1982; Accepted January 7, 1983

\begin{abstract}
Two types of glial fibrillary acidic protein-positive $\left(\mathrm{GFAP}^{+}\right)$astrocytes were found in cultures of developing rat optic nerve. Type 1 astrocytes had a fibroblast-like morphology, did not bind tetanus toxin or the monoclonal antibody A2B5 (both of which bind to specific polysialogangliosides), and were stimulated to divide by an extract of bovine pituitary and by epidermal growth factor (EGF). Type 2 astrocytes had a neuron-like morphology, bound tetanus toxin and A2B5 antibody, and were not stimulated to divide by bovine pituitary extract or by EGF. Although both types of astrocytes were present in cultures of white matter, only type 1 astrocytes were found in cultures of gray matter. Astrocytes did not convert from one type to the other in culture: while many type 1 astrocytes adopted a neuron-like morphology when exposed to dibutyryl cyclic adenosine $3^{\prime}: 5^{\prime}-$ monophosphate, or pituitary or brain extracts, especially in serum-free medium, such morphologically altered cells did not bind tetanus toxin or A2B5 antibody. Although small numbers of tetanus toxin-binding, $\mathrm{A}_{2} \mathrm{~B}^{+}{ }^{+} \mathrm{GFAP}^{+}$cells were present in suspensions of freshly dissected, neonatal optic nerves, most of the type 2 astrocytes in cultures of such optic nerves developed from tetanus toxinbinding, A2B5 ${ }^{+}, \mathrm{GFAP}^{-}$cells, which were induced to express GFAP by the culture conditions. Since type 2 astrocytes have a neuron-like morphology and bind tetanus toxin and A2B5 antibody, these ligands cannot be used on their own as neuron-specific markers in central nervous system cultures.
\end{abstract}

Conventional and monoclonal antibodies and certain protein toxins, such as tetanus toxin, are increasingly being used to distinguish the major types of cells in the vertebrate nervous system, particularly in tissue culture (Raff et al., 1979; McKay et al., 1981; Mirsky, 1982; Schachner, 1982). As more of these ligands are produced and/or characterized, it is inevitable that the major types of neural cells will be progressively subdivided into biochemically distinct subtypes. Here we report that two types of astrocytes can be distinguished in cultures of developing rat white matter on the basis of morphology, tetanus toxin and monoclonal antibody binding, and growth properties.

Tetanus toxin, which binds to the di- and trisialogan-

\footnotetext{
${ }^{1}$ We thank Dr F. Walsh and Drs. J. Wood and B. Anderton for providing the A2B5 and anti-neurofilament antibodies, respectively, Drs. S. Kellie and P. H. Fishman for purified gangliosides, Dr. P. Patterson for suggesting the A2B5 pulse experiment, and Dr. J. Brockes for helpful comments on the manuscript.

${ }^{2}$ To whom correspondence should be addressed.

${ }^{3}$ Present address: Institute of Neurology, Queen Square, London WC1N 3BG, England.
}

gliosides GD1b and GT1 (Van Heyningen, 1963), is widely used as a specific marker for vertebrate neurons in culture (Dimpfel et al., 1975; Mirsky et al., 1978), while glial fibrillary acidic protein (GFAP), the major subunit of glial filaments, is used as a marker for vertebrate astrocytes both in culture (Raff et al., 1979) and in tissue sections (Bignami et al., 1972). We were therefore surprised in a previous study to find cells in cultures of neonatal rat optic nerve that were labeled in immunofluorescence assays by both tetanus toxin and anti-GFAP antibodies; whereas the $\mathrm{GFAP}^{+}$astrocytes that did not bind tetanus toxin were mostly large, flat, fibroblast-like cells, the tetanus toxin-binding astrocytes were usually more neuron (or oligodendrocyte)-like, being smaller and darker and having several branching processes (Raff et al., 1979). Neuron-like cells that bind tetanus toxin and contain GFAP have also been observed by Stallcup (1981), who has, in addition, defined a cell surface glycoprotein (NG2) expressed on cells with a mixture of neuronal and glial properties (Stallcup, 1981; Wilson et al., 1981).

In the present study we have compared the astrocytebinding properties of tetanus toxin and the monoclonal 
antibody, A2B5, which binds to a tetrasialoganglioside (GQ) (Eisenbarth et al., 1979). Although A2B5 was originally thought to bind only to neurons in chick central (CNS) and peripheral nervous system tissues (Eisenbarth et al., 1979), it has recently been reported to bind to a small proportion of astrocytes and oligodendrocytes (as well as to the majority of neurons) in cultures of a variety of vertebrate CNS tissues (Berg and Schachner, 1982; Schnitzer and Schachner, 1982). We show that in cultures of optic nerve, both tetanus toxin and A2B5 antibody bind to the great majority of $\mathrm{GFAP}^{+}$astrocytes that have a characteristic neuron-like morphology, but only to a small minority of $\mathrm{GFAP}^{+}$astrocytes with a fibroblastlike morphology. We shall subsequently refer to the fibroblast-like astrocytes that do not bind tetanus toxin or A2B5 antibody as type 1 astrocytes and to the neuronlike astrocytes that bind these ligands as type 2 astrocytes. We provide biochemical evidence that type 2 astrocytes synthesize the polysialogangliosides recognized by tetanus toxin and A2B5 antibody and demonstrate that, while both type 1 and type 2 astrocytes are present in cultures of developing white matter, only type 1 astrocytes are present in cultures of developing gray matter. Finally, we show that, in culture, the two types of astrocytes have different growth properties and seem not to convert from one type to the other.

\section{Materials and Methods}

Cell suspensions and cultures. Cell suspensions of optic nerve, corpus callosum, cerebellum, cerebral cortex, and leptomeninges were prepared from perinatal Sprague-Dawley rats as previously described (Raff et al., 1979) (except that, in the case of optic nerves, only the nerves and anterior chiasm and not the optic tracts were taken to avoid contamination from neurons in the small pieces of cerebrum that sometimes adhered to the tracts). Cell suspensions from adult (12- to 14-week) rat optic nerves were prepared by cutting the nerves into small pieces and incubating them for $60 \mathrm{~min}$ at $37^{\circ} \mathrm{C}$ in $1 \mathrm{ml}$ of Eagle's Minimal Essential Medium (MEM) with $0.02 \mathrm{M}$ HEPES buffer (MEM-HEPES) and an equal volume of $0.25 \%(\mathrm{w} / \mathrm{v})$ trypsin (Difco) and $0.02 \%(\mathrm{w} / \mathrm{v})$ EDTA in Tris-buffered saline (trypsin/EDTA) with collagenase (Worthington) added to a final concentration of $0.02 \%$; after another 15-min incubation in trypsin/EDTA, the cells were dissociated in DNAse (Sigma, $0.04 \mathrm{mg} / \mathrm{ml}$ ) and trypsin inhibitor (Sigma, $0.05 \mathrm{mg} / \mathrm{ml}$ ) in $\mathrm{Ca}^{2+}$ - and $\mathrm{Mg}^{2+}$. free MEM by repeated pipetting in a $2-\mathrm{ml}$ graduated pipette. Cells from surgically lesioned, adult corpus callosum were prepared as previously described (Lindsay et al., 1982). After dissociation, all cells were kept and washed in MEM-HEPES containing 10\% heat-inactivated $\left(56^{\circ} \mathrm{C}\right.$ for $\left.30 \mathrm{~min}\right)$ fetal calf serum (FCS) except when they were cultured. The number of viable cells was determined by counting in a hemocytometer in the presence of trypan blue.

Cells were cultured in Dulbecco's modified Eagle's medium containing $10 \%$ FCS (DMEM) at $37^{\circ} \mathrm{C}$ in a humidified atmosphere of $5 \% \mathrm{CO}_{2}$ and $95 \%$ air, either on polylysine-coated $13-\mathrm{mm}$ glass coverslips, as previously described (Raff et al., 1979), or on polylysine-coated 35$\mathrm{mm}$ Nunc tissue culture dishes. In the case of the optic nerve and leptomeninges, approximately 20,000 live cells in $40 \mu \mathrm{l}$ of DMEM were plated at the center of each coverslip or culture dish, and another $500 \mu \mathrm{l}$ (for coverslips) or $2 \mathrm{ml}$ (for culture dishes) of DMEM was added after 2 to $6 \mathrm{hr}$. For corpus callosum and cerebellum, approximately $10^{5}$ live cells were plated on coverslips or culture dishes in $100 \mu \mathrm{l}$ of DMEM before additional medium was added. Plating efficiencies assessed at $6 \mathrm{hr}$ were between 20 and $30 \%$.

Purified astrocytes were prepared by a modification of the procedure of McCarthy and de Vellis (1980): $2 \times 10^{7}$ cells dissociated from the cerebral cortex of 2-day rats were cultured for 9 to 10 days in Falcon tissue culture flasks $\left(75 \mathrm{~cm}^{2}\right.$ surface area). The flasks were then shaken overnight on a rotary platform and the remaining adherent cells were removed from the flask with trypsin/ EDTA and replated in $35-\mathrm{mm}$ Nunc culture dishes ( $\sim 40,000$ cells/dish). When tested after 3 to 10 days, 85 to $95 \%$ of the cells were $\mathrm{GFAP}^{+}$. In some experiments, purified astrocytes were maintained in serum-free medium, consisting of DMEM with added glucose $(5.6 \mathrm{mg} /$ $\mathrm{ml})$, bovine insulin $(0.5 \mu \mathrm{g} / \mathrm{ml})$, human transferrin $(100$ $\mu \mathrm{g} / \mathrm{ml})$, bovine serum albumin $(100 \mu \mathrm{g} / \mathrm{ml})$, progesterone $(0.06 \mathrm{ng} / \mathrm{ml})$, putrescine $(16 \mu \mathrm{g} / \mathrm{ml})$, selenium $(0.04 \mathrm{ng} /$ $\mathrm{ml})$, thyroxine $(0.4 \mathrm{ng} / \mathrm{ml})$, and tri-iodothyronine $(0.3 \mathrm{ng} /$ ml) (Bottenstein and Sato, 1979).

Antibodies. All of the antibodies used in these studies have been described previously: rabbit anti-human GFAP serum (Pruss, 1979) was used at a dilution of 1:500, rabbit anti-tetanus toxoid serum (Mirsky et al., 1978) was used at 1:100, mouse anti-tetanus toxoid serum (Raff et al., 1979) was used at 1:100, and rabbit anti-neurofilament serum (anti-NF), made against the 210,000-dalton subunit protein of bovine neurofilaments (Anderton et al., 1980 ), was used at 1:20. Two monoclonal antibodies were used: A2B5 (Eisenbarth et al., 1979) (ascites fluid from hybridoma-bearing mice used at 1:80) and RT97, which was made against rat neurofilaments and reacts with the 210,000- and 155,000-dalton subunits of these filaments (Wood and Anderton, 1981) (ascites fluid used at 1:100). The rabbit antibodies were visualized in indirect immunofluorescence assays with fluorescein-coupled goat antirabbit Ig (G anti-RIg-F1; Nordic batch no. 3-277) which had been absorbed with mouse IgG coupled to Sepharose $4 \mathrm{~B}$ and diluted 1:100. The mouse antibodies were visualized with rhodamine-coupled goat anti-mouse Ig (G anti-MIg-Rd; Cappel batch no. 2-773) absorbed with rabbit IgG coupled to Sepharose 4B and diluted 1:100. In control studies, normal ascites fluid from mice carrying the NS-1 myeloma line or supernalants from cultures of NS-1 cells were used. Tetanus toxin was a gift from Dr. R. O. Thomson, Wellcome Research Laboratories; it was used at $1 \mu \mathrm{g} / \mathrm{ml}$ as previously described (Raff et al., 1979). All antibodies and tetanus toxin were diluted in MEMHEPES containing $10 \%$ FCS and $0.02 \%$ sodium azide.

Growth factors, tissue extracts, and cholera toxin. Epidermal growth factor (EGF) was purchased from Collaborative Research. Bovine pituitary extract was prepared as previously described (Brockes et al., 1979), and adult rat brain extract was prepared and used as described by Lim et al. (1973). Cholera toxin was purchased from Schwarz/Mann. 
Immunofluorescence assays. Two fluorochrome indirect immunofluorescence assays were carried out as previously described (Raff et al., 1979). Cells growing on glass coverslips or $35-\mathrm{mm}$ culture dishes were exposed to tetanus toxin (followed by mouse anti-tetanus toxoid serum) or A2B5 monoclonal antibody, washed in MEMHEPES, and then incubated in G anti-MIg Rd. After washing, the cells were fixed for $10 \mathrm{~min}$ at $-20^{\circ} \mathrm{C}$ in $5 \%$ acetic acid in ethanol (acid-alcohol) and then exposed to rabbit anti-GFAP or rabbit anti-NF serum followed by G anti-RIg-Fl. All incubations were for $25 \mathrm{~min}$ at room temperature. After washing, coverslips were mounted (or placed over the cells on culture dishes) in glycerol and sealed with nail varnish. In some experiments, cells were double labeled with tetanus toxin and A2B5 antibody by exposing them to tetanus toxin, then simultaneously to rabbit anti-tetanus toxoid serum and A2B5 antibody followed by G anti-RIg-Fl and G anti-MIg-Rd. In other experiments, cells were fixed in acid-alcohol and exposed to monoclonal anti-NF antibody followed by G anti-MIgRd.

Immunofluorescence labeling of cells in suspension (either freshly dissociated from tissue or removed from culture dishes with trypsin/EDTA) was carried out by incubating 30,000 to 40,000 cells in $20 \mu \mathrm{l}$ of A2B5 antibody (or tetanus toxin followed by mouse anti-tetanus toxoid) in $0.4 \times 4 \mathrm{~cm}$ plastic precipitin tubes, followed by a single wash and a second incubation in $20 \mu \mathrm{l}$ of G anti-MIg-Rd. $\Lambda l l$ incubations were for $25 \mathrm{~min}$ at room temperature and were carried out in MEM-HEPES with $0.2 \%$ sodium azide and $50 \%(\mathrm{v} / \mathrm{v})$ heat-inactivated normal goat serum. (The latter served to saturate the Fc receptors on macrophages.) After washing, the cells were resuspended in MEM-HEPES without serum and allowed to adhere to polylysine-coated coverslips for $30 \mathrm{~min}$ at room temperature. The cells were then fixed in acid-alcohol, labeled with rabbit anti-GFAP serum followed by G anti-RIg-Fl, and mounted as described above.

When tetanus toxin was omitted, or the monoclonal antibodies or antisera were replaced by normal ascites fluid, supernatant, or serum, no staining was seen, except for the characteristic staining of macrophages (Raff et al., 1979).

Killing $\mathrm{A}_{2 \mathrm{~B} 5^{+}}$cells in suspensions of optic nerve with A2B5 antibody and complement. Approximately 40,000 live cells dissociated from 7-day optic nerves were incubated in $200 \mu \mathrm{l}$ of A2B5 antibody and rabbit complement, normal ascites fluid and rabbit complement (which was absorbed with agar as described by Cohen and Schlesinger (1970)), or MEM-HEPES with 10\% FCS for $40 \mathrm{~min}$ at $37^{\circ} \mathrm{C}$. After washing, the cells were counted and then cultured in polylysine-coated $35-\mathrm{mm}$ Nunc culture dishes. The final dilution of the A2B5 and normal ascites fluid was 1:50 and of the complement, 1:10.

Time-lapse video recording. Optic nerve cells growing in Falcon tissue culture flasks were studied by time-lapse video using a Zeiss inverted microscope equipped with phase contrast optics and coupled to a silicon-intensified target video camera (RT Laboratories) and a video recording system. The stage was maintained at approximately $37^{\circ} \mathrm{C}$ by means of a fan heater.

Autoradiography. Cells growing on polylysine-coated coverslips were exposed to $\left[{ }^{3} \mathrm{H}\right]$ thymidine $(2 \mathrm{Ci} / \mathrm{mmol}$, Amersham) at $2 \mu \mathrm{Ci} / \mathrm{ml}$ for $24 \mathrm{hr}$. After thorough washing, the cells were labeled with A2B5 antibody and antiGFAP serum as described above. The coverslips were coated with Ilford $\mathrm{K} 2$ emulsion, stored at $-70^{\circ} \mathrm{C}$ for 72 hr in the dark, developed with Ilford Super Contrast FF, mounted, and examined as described above.

Ganglioside biosynthesis. Cells from 7-day corpus callosum, optic nerve, and leptomeninges were cultured in 60-mm Falcon tissue culture dishes in MEM with 10\% FCS. Typically, corpus callosum and leptomeninges from 12 rats were each plated on four to six dishes, while optic nerves from 30 rats were plated on three dishes. After 24 or $48 \mathrm{hr}$, half of the medium was replaced with $2 \mathrm{ml}$ of medium containing $1 \mu \mathrm{Ci}$ of $\mathrm{D}-\left[U_{-}{ }^{14} \mathrm{C}\right]$ glucosamine hydrochloride $(309 \mathrm{mCi} / \mathrm{mmol}$, Amersham). The medium with isotope was changed after another $48 \mathrm{hr}$ and the cells were harvested on the 6th or 7th day of culture by scraping with a rubber policeman in $2 \mathrm{ml}$ of methanol (all organic solvents were Analar grade from Hopkin and Williams) after washing three times with phosphatebuffered saline, pH 7.3.

Gangliosides were extracted by the Suzuki (1965) modification of the Folch-Pi procedure (Folch-Pi et al., 1957). Briefly, the cells from $6 \times 60 \mathrm{~mm}$ dishes were collected in $18 \mathrm{ml}$ of methanol, to which was added chloroform to a final ratio of chloroform to methanol of 2:1. The extraction mixture was sonicated in a Dawe bath sonicator for $3 \mathrm{~min}$ before shaking for $60 \mathrm{~min}$ on a rotary shaker. The cell debris was filtered off on a Whatman No. 1 filter paper and the retentate was extracted further with chloroform:methanol in the reverse ratio (1:2) containing 5\% water. The combined extracts were adjusted to the FolchPi ratio of chloroform:methanol:water $(8: 4: 3)$ by the addition of chloroform and $0.88 \%$ aqueous $\mathrm{KCl}$. Aliquots of the resulting upper and lower phases were counted in a Beckman scintillation counter, which indicated that > $95 \%$ of the radiolabeled material was recovered in the upper methanol/water phase. The extracted gangliosides were desalted by dialysis of the Folch-Pi upper phase (after reduction of the methanol content by rotary evaporation for $10 \mathrm{~min}$ at $60^{\circ} \mathrm{C}$ under vacuum) in Spectrapor 3 dialysis tubing against $4 \times 10$ liters of distilled water. The salt-free ganglioside extract was lyophilized and stored at $-20^{\circ} \mathrm{C}$.

Gangliosides were separated on silica gel $60 \mathrm{~F}_{254}$ precoated, 0.25 -mm thick, $20 \times 20 \mathrm{~cm}$ thin-layer chromatography (TLC) plates (Merck, Darmstadt). Aliquots of the freeze-dried samples and standard gangliosides (bovine brain mixed gangliosides (Sigma) and pure, or partially purified, GM3, GM1, GD1 ${ }_{a}, G D 1_{b}, G T$, and GQ (generous gifts from Dr. S. Kellie, University of Leicester, and Dr. P. H. Fishman, National Institutes of Health, Bethesda, MD) were taken up in chloroform:methanol 1:1 and applied as thin streaks $2 \mathrm{~cm}$ from the edge of the TLC plate. Development of the TLC plate was performed according to the method of Rosner and Mertz (1982), using the solvent system, chloroform:methanol:12 mM $\mathrm{MgCl}_{2}: 15 \mathrm{~N} \mathrm{NH}_{4} \mathrm{OH}$ (60:35.5:8:0.2) for $90 \mathrm{~min}$. Gangliosides, referred to by the Svennerholm (1963) nomenclature, were visualized with the resorcinol spray reagent (Svennerholm, 1957) and incubation at $140^{\circ} \mathrm{C}$ for $15 \mathrm{~min}$. 
The positions of radiolabeled bands were detected by counting lanes of the developed TLC plate in a Berthold thin-layer plate scanner. The scans were recorded on a Berthold strip chart recorder.

\section{Results}

Two types of astrocytes are present in cultures of optic nerve. When 5- to 11-day rat optic nerve cells growing on polylysine-coated glass coverslips were studied by indirect immunofluorescence after 3 to 5 days in culture, none of the cells were labeled by rabbit or monoclonal anti-NF antibodies, suggesting that the cultures did not contain neurons. The percentage of $\mathrm{GFAP}^{+}$cells in such cultures varied between 4 and 15\%: of the $\mathrm{GFAP}^{+}$cells, 25 to $75 \%$ had a process-bearing, neuron-like morphology, while the remainder had a fibroblast-like morphology. More than $95 \%$ of the neuron-like $\mathrm{GFAP}^{+}$cells were labeled by tetanus toxin and A2B5 antibody, whereas less than $2 \%$ of the fibroblast-like $\mathrm{GFAP}^{+}$cells were labeled by these ligands (Fig. 1). When optic nerve cultures were doubly labeled with tetanus toxin and A2B5 antibody, more than $90 \%$ of the cells labeled with one ligand were also labeled with the other (not shown). For convenience, we shall refer to the tetanus toxin-binding, $\mathrm{A} 2 \mathrm{~B}^{+}$astrocytes with a neuron (or oligodendrocyte)-like morphology as type 2 astrocytes, and to the fibroblastlike astrocytes that did not bind these ligands as type 1 astrocytes. In optic nerve cultures prepared from 16- to 17-day embryos and assayed after 3 days in vitro, only 5 to $10 \%$ of the $\mathrm{GFAP}^{+}$cells had a type 2 morphology, but, as was the case in neonatal optic nerve cultures, more than $95 \%$ of these neuron-like cells were labeled by tetanus toxin and A2B5 antibody (Fig. 2).

In all optic nerve cultures, the type 2 astrocytes were rapidly overgrown by other cells (mainly $\mathrm{GFAP}^{-}$fibroblast-like cells) and few type 2 cells remained after 10 days in culture. However, if the cultures were irradiated $(2000 \mathrm{R})$, or treated with cytosine arabinoside $\left(10^{-6} \mathrm{M}\right)$ or 5-fluorodeoxyuridine $\left(10^{-5} \mathrm{M}\right)+$ uridine $\left(2 \times 10^{-5} \mathrm{M}\right)$, then tetanus toxin-binding, $\mathrm{A}^{+} \mathrm{B5}^{+}, \mathrm{GFAP}^{+}$cells were still found after 3 weeks, although most of these cells were larger and flatter than type 2 astrocytes in younger cultures and were, therefore, less readily distinguishable on morphological criteria from type 1 astrocytes (not shown).
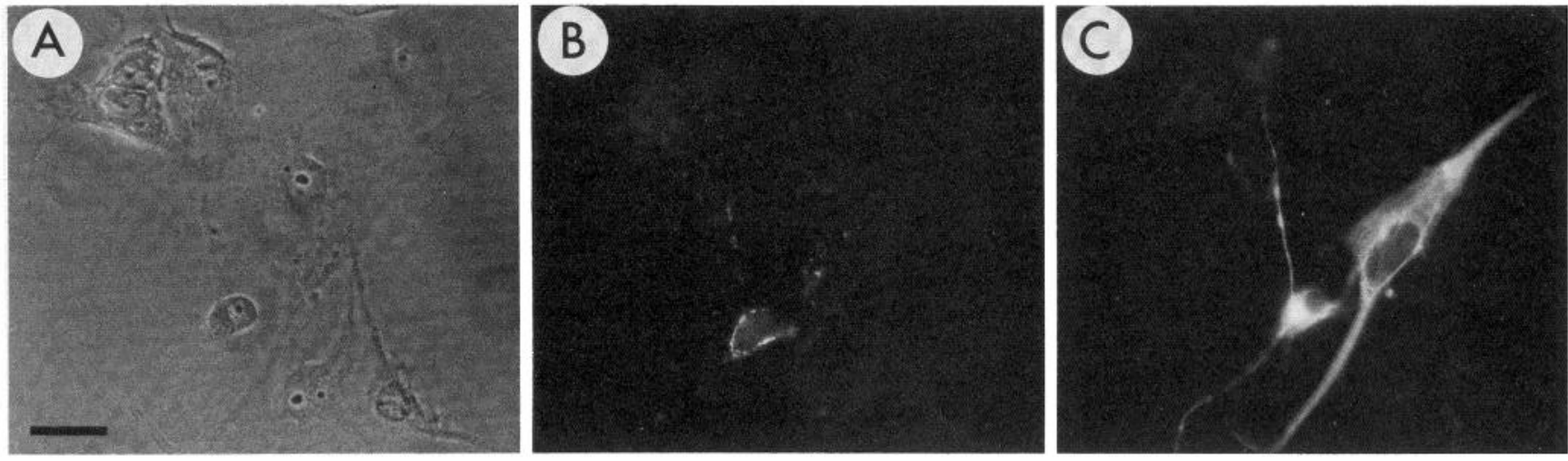

Figure 1. A tetanus toxin-binding, neuron-like astrocyte and a non-tetanus toxin-binding, fibroblast-like astrocyte in a culture of 7-day optic nerve. Cells were labeled after 3 days in culture with tetanus toxin, then mouse anti-tetanus toxoid, followed by G anti-MIg-Rd; after fixation in acid-alcohol, the cells were labeled with rabbit anti-GFAP followed by G anti-RIg-Fl. The cells were viewed with phase contrast $(A)$, rhodamine $(B)$, and fluorescein $(C)$ optics. The scale bar $=20 \mu \mathrm{m}$ in this and the following figures.
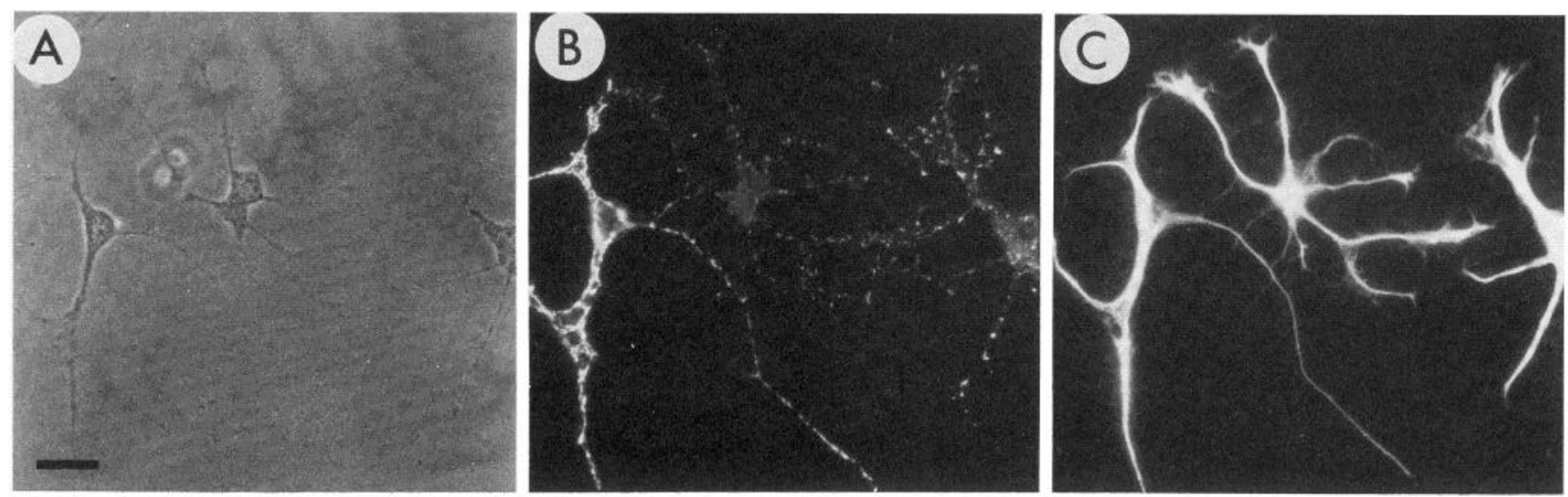

Figure 2. A2B5 ${ }^{+}$type 2 astrocytes in a culture of 17-day embryonic optic nerve. Cells were labeled after 3 days in culture with A2B5 antibody followed by G anti-MIg-Rd. After fixation in acid-alcohol, the cells were labeled for GFAP and viewed as described for Figure 1. 

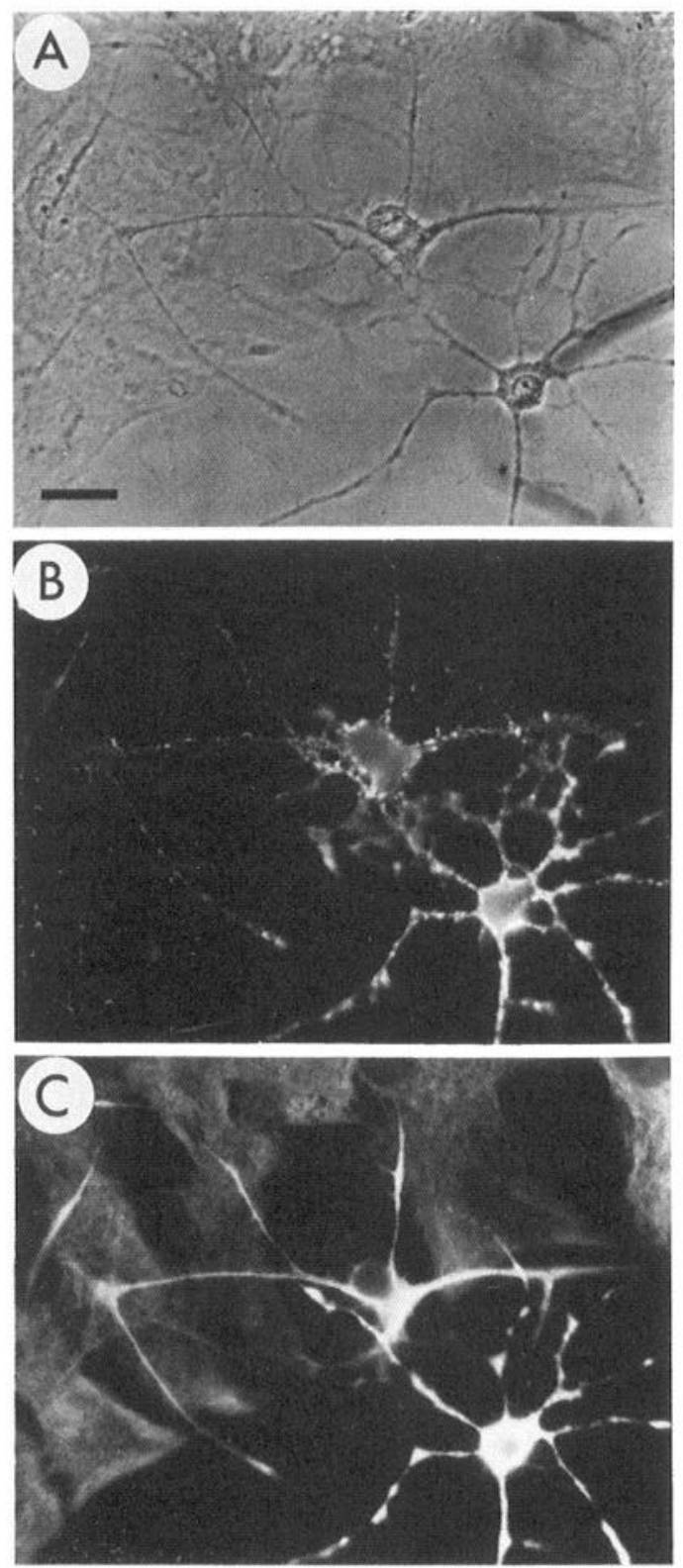

Figure $3 \mathrm{~A}^{\mathrm{B} 5}{ }^{+}$type 2 astrocytes and $\mathrm{A} 2 \mathrm{B5}^{-}$type 1 astrocytes in a multiply passaged culture of corpus callosum. Corpus callosum cells from a 5-day rat were plated in a culture dish and passaged weekly for 4 weeks before being plated on polylysine-coated glass coverslips and labeled after 6 days with A2B5 and anti-GFAP and viewed as described for Figure 2.

Type 2 astrocytes are found mainly in cultures of white matter. Not all CNS cultures contained type 2 astrocytes. Cultures of leptomeninges prepared from the cerebral hemispheres of 5- to 8-day rats always contained some astrocytes (and often occasional neurofilamentcontaining neurons), presumably from the underlying cerebral cortex. All of the $\mathrm{GFAP}^{+}$cells in such cultures had the morphology of type 1 astrocytes and none of them bound tetanus toxin or A2B5 antibody. On the other hand, cultures prepared directly from the cerebral cortex itself always contained substantial numbers of tetanus toxin-binding and $\mathrm{A} 2 \mathrm{~B} 5^{+}$type 2 astrocytes, probably derived from white matter underlying the cortex.
When cultures of 5- to 8-day corpus callosum were doubly labeled after 3 to 10 days, 40 to $60 \%$ of $\mathrm{GFAP}^{+}$ cells with type 2 morphology bound tetanus toxin and A2B5 antibody, and more than $90 \%$ of them bound these ligands after 20 days in culture. Less than $5 \%$ of the fibroblast-like astrocytes in these cultures were labeled by tetanus toxin or A2B5 antibody. When the cells in corpus callosum cultures were passaged repeatedly for up to 3 months, both type 1 and type 2 astrocytes persisted and retained their characteristic antigenic and morphological phenotypes (Fig. 3). Unlike the case of optic nerve cultures, $\mathrm{GFAP}^{-}$, fibroblast-like cells did not overgrow corpus callosum cultures, presumably because these cultures contained few leptomeningeal cells.

It was often difficult to be certain of the tetanus toxinor A2B5-binding properties of astrocytes in cultures that contained significant numbers of neurons, such as cultures of cerebral cortex and cerebellum (and even of corpus callosum, unless special care was taken to avoid contamination with the overlying cerebral hemispheres), because the neuronal processes tended to ramify on the surface of astrocytes and run along astrocytic processes; also, the great majority of neuronal processes (identified by the binding of rabbit or monoclonal anti-NF antibody) bound tetanus toxin and A2B5 antibody in all of the CNS cultures we have examined (not shown). This is presumably why the binding of tetanus toxin to type 2 astrocytes in corpus callosum cultures was originally overlooked (Raff et al., 1979). To overcome this problem, and to quantify the proportions of type 1 and type 2 astrocytes in cultures of various tissues more accurately, cells were grown on polylysine-coated tissue culture dishes and double labeled after they were removed from the dish with trypsin/EDTA. (Fortunately, most of the binding sites for tetanus toxin and A2B5 antibody are trypsin resistant.) The results of such experiments on 7-day tissues studied after 5 days in culture are shown in Table I: whereas 30 to $50 \%$ of the $\mathrm{GFAP}^{+}$cells in optic nerve and corpus callosum cultures were labeled by tetanus toxin and A2B5 antibody, less than 5\% of such cells in cultures of cerebellum bound these ligands, and none of the $\mathrm{GFAP}^{+}$cells in cultures of leptomeninges bound them.

Cells in neuron-free cultures of white matter synthesize polysialogangliosides. To exclude the unlikely pos-

TABLE I

Binding of tetanus toxin and A2B5 antibody to astrocytes in cell suspensions from cultured neural tissues

Dissociated cells from 7-day rat tissues were cultured on polylysinecoated dishes for 5 days before being removed from the dish with trypsin/EDTA and labeled. The results in this and the following tables are expressed as the mean $\pm \mathrm{SD}$ of at least three separate experiments. Proportion (\%) of $\mathrm{GFAP}^{+}$Cells La-

Cultures GFAP $^{+}$Cells beled with

(\%) Tetanus
toxin A2B5

Optic nerve

Corpus callosum

Cerebellum

Leptomeninges (+ cerebral cortex)
$32 \pm 5 \quad 30 \pm 8$

$4 \pm 2$

$\begin{array}{rrr}66 \pm 6 & 43 \pm 3 & 40 \pm 9 \\ 24 \pm 7 & 2 \pm 2 & 1 \pm 1\end{array}$

$\begin{array}{lll}1 \pm 1 & 0 & 0\end{array}$



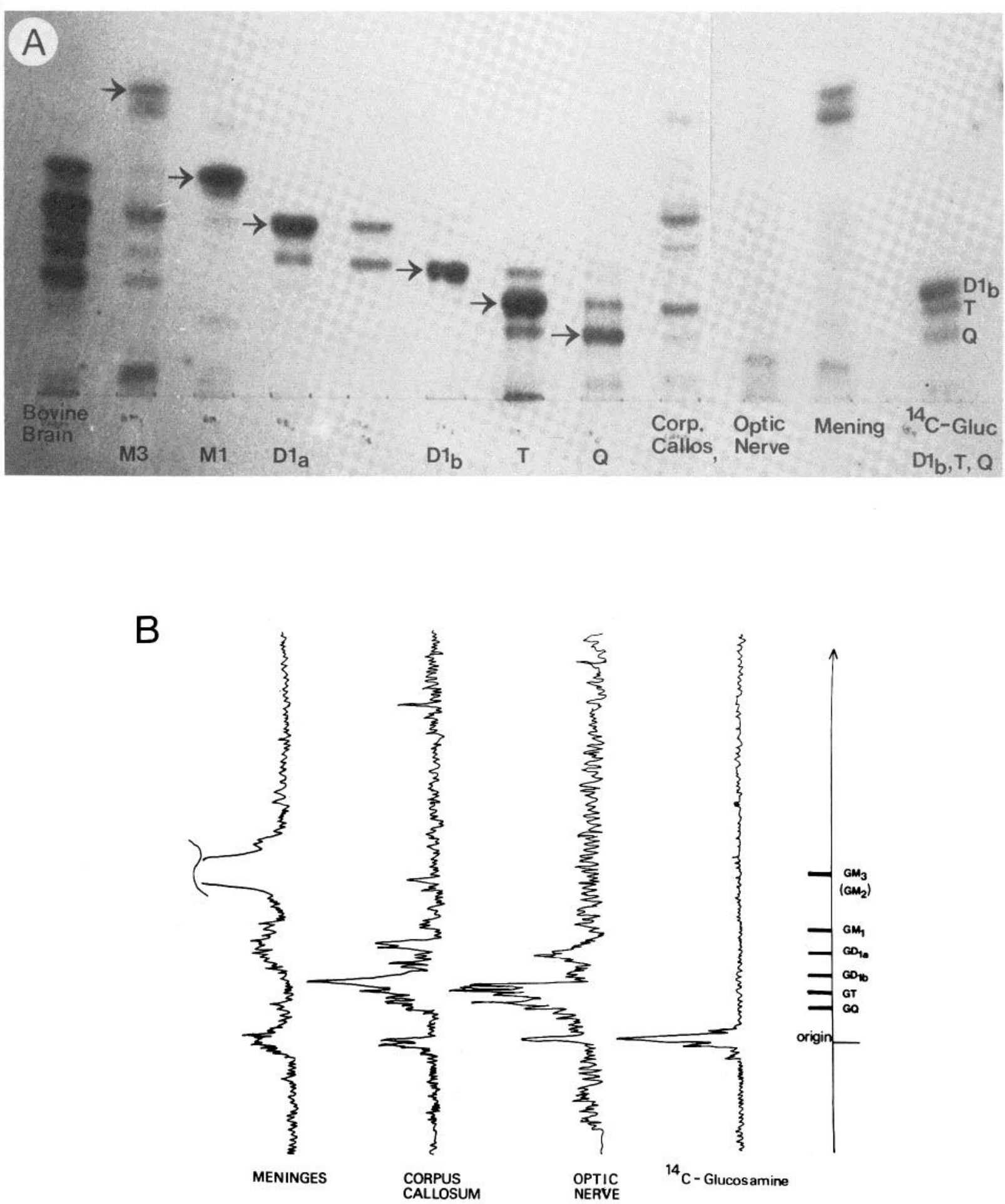

Figure 4. Gangliosides in extracts of cultures of 7-day corpus callosum, optic nerve, and leptomeninges. Cultures were exposed to $\left[{ }^{14} \mathrm{C}\right]$ glucosamine and the gangliosides were extracted and separated on TLC plates as described under "Materials and Methods." In $A$, the separated gangliosides were visualized with a resorcinol spray reagent and were compared with bovine brain gangliosides and standards of mono-, di-, tri-, and tetrasialogangliosides (arrows indicate the positions of the relevant standard gangliosides). Note that GT and GQ bands are present in extracts of corpus callosum cultures but not leptomeningeal cultures. Little or no gangliosides are detected by the resorcinol in extracts of optic nerve cultures because of the relatively small numbers of cells in such cultures. In $B$, the positions of radiolabeled peaks were detected by scanning the lanes of the developed TLC plates shown in $A$. The radioactive peaks correspond to gangliosides, synthesized in vitro, that incorporated the $\left[{ }^{14} \mathrm{C}\right] \mathrm{glucosamine}$, since the glucosamine itself does not migrate in the solvent system used. Approximately $2000 \mathrm{cpm}$ were applied to both the corpus callosum and leptomeninges lanes, which were scanned for $20 \mathrm{~min}$, whereas only $300 \mathrm{cpm}$ were applied to the optic nerve lane, which was therefore scanned for $150 \mathrm{~min}$. Radioactive peaks are seen in regions corresponding to GT and GQ in optic nerve and corpus callosum lanes but not in the leptomeninges lane; in the latter lane radioactive peaks are seen in regions corresponding to monosialogangliosides. 
sibility that type 2 astrocytes acquired the polysialogangliosides recognized by tetanus toxin and A2B5 antibody from axons in vivo, or during the preparation or culturing of white matter cell suspensions, we exposed cultures of 4- to 7-day corpus callosum, optic nerve, and leptomeninges to radioactive glucosamine hydrochloride and looked for de novo synthesis of polysialogangliosides. At the time of harvesting the cells for ganglioside extraction and analysis, cultures of corpus callosum, optic nerve, and leptomeninges contained 65 to $75 \%, 6$ to $10 \%$, and approximately $1 \% \mathrm{GFAP}^{+}$cells, respectively. When sister cultures prepared from the same cell suspensions were labeled with anti-NF antibodies to detect neurons, no cells were labeled in optic nerve cultures, and $<1 \%$ were labeled in cultures of corpus callosum and leptomeninges.

When the extracted gangliosides were separated on TLC plates and visualized with the resorcinol spray reagent (Fig. $4 A$ ), corpus callosum cultures were found to be rich in GT and contained detectable levels of GQ, $\mathrm{GD1}_{\mathrm{a}}$, and monosialogangliosides, whereas only monosialogangliosides were detectable in leptomeningeal cultures. Because of the very low yield of cells from optic nerve cultures, ganglioside bands were not detectable by this method. On the other hand, when the TLC plates were scanned for radioactivity, radioactivity was detected in the regions corresponding to di-, tri-, and tetrasialogangliosides in both corpus callosum and optic nerve cultures but not in cultures of leptomeninges (Fig. $4 B$ ).

Tetanus toxin and A2B5 antibody bind to some astrocytes in cell suspensions prepared from freshly isolated white matter. To exclude the possibility that type 2 astrocytes were artifactually induced to synthesize tetanus toxin- and A2B5 antibody-binding gangliosides by conditions in tissue culture, we studied cells dissociated from freshly isolated 7- and 14-day optic nerve, corpus callosum, cerebellum, and leptomeninges. As shown in Table II, a substantial proportion of $\mathrm{GFAP}^{+}$cells from optic nerve and corpus callosum bound tetanus toxin (Fig. 5) and A2B5 antibody, whereas very few $\mathrm{GFAP}^{+}$

TABLE II

Binding of tetanus toxin and A2B5 antibody to astrocytes in cell suspensions from freshly dissected neural tissues

\begin{tabular}{|c|c|c|c|c|c|}
\hline \multirow{2}{*}{ Cells } & \multicolumn{3}{|c|}{$\begin{array}{l}\text { Proportion (\%) of Total Cells La- } \\
\text { beled with }\end{array}$} & \multicolumn{2}{|c|}{$\begin{array}{l}\text { Proportion (\%) of } \\
\text { GFAP }^{+} \text {Cells La- } \\
\text { beled with }\end{array}$} \\
\hline & Anti-GFAP & $\begin{array}{l}\text { Tetanus } \\
\text { toxin }\end{array}$ & A2B5 & $\begin{array}{c}\text { Tetanus } \\
\text { toxin }\end{array}$ & A2B5 \\
\hline \multicolumn{6}{|l|}{ Optic nerve } \\
\hline $7 \mathrm{~d}$ & $6 \pm 4$ & $21 \pm 8$ & $24 \pm 7$ & $8 \pm 3$ & $6 \pm 4$ \\
\hline $14 \mathrm{~d}$ & $7 \pm 5$ & $21 \pm 6$ & $26 \pm 8$ & $13 \pm 4$ & $12 \pm 1$ \\
\hline \multicolumn{6}{|c|}{ Corpus callosum } \\
\hline $7 \mathrm{~d}$ & $13 \pm 4$ & $32 \pm 8$ & $31 \pm 6$ & $37 \pm 4$ & $45 \pm 4$ \\
\hline $14 \mathrm{~d}$ & $10 \pm 1$ & $33 \pm 7$ & $30 \pm 5$ & $36 \pm 5$ & $40 \pm 10$ \\
\hline \multicolumn{6}{|l|}{ Cerebellum } \\
\hline $7 \mathrm{~d}$ & $4 \pm 1$ & $37 \pm 8$ & $32 \pm 4$ & $1 \pm 1$ & $1 \pm 1$ \\
\hline $14 \mathrm{~d}$ & $4 \pm 2$ & $45 \pm 6$ & $42 \pm 8$ & $1 \pm 1$ & $1 \pm 1$ \\
\hline \multicolumn{6}{|c|}{$\begin{array}{l}\text { Leptomeninges } \\
\text { (plus cerebral } \\
\text { cortex) }\end{array}$} \\
\hline $7 \mathrm{~d}$ & $10 \pm 4$ & $4 \pm 3$ & $3 \pm 3$ & 0 & 0 \\
\hline $14 \mathrm{~d}$ & $4 \pm 3$ & $<1$ & $2 \pm 1$ & 0 & 0 \\
\hline
\end{tabular}
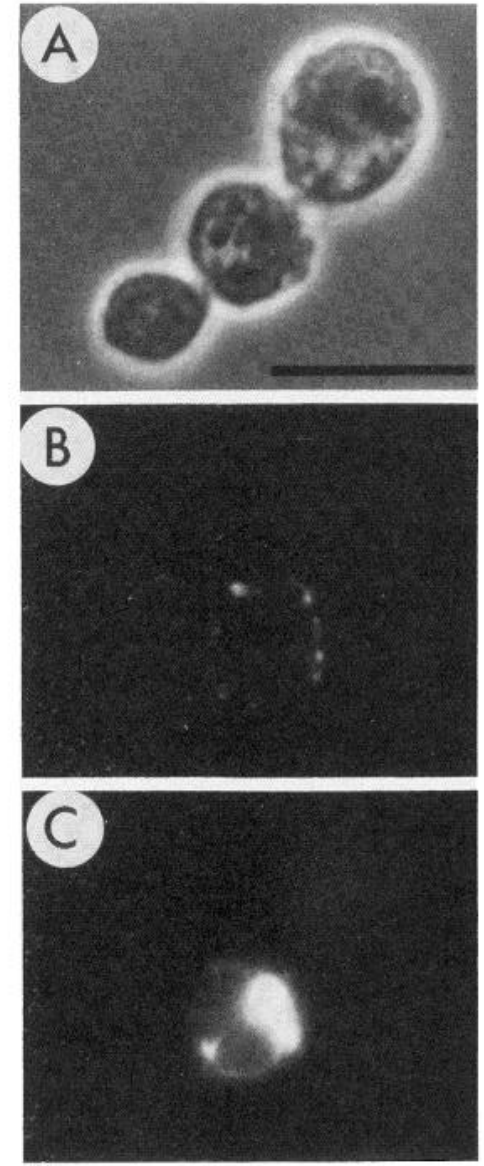

Figure 5. Tetanus toxin-binding, $\mathrm{GFAP}^{+}$cell in a cell suspension prepared from freshly dissected 7-day optic nerve. The cells were labeled in suspension with tetanus toxin, mouse antitetanus toxoid, and G anti-MIg-Rd and then were allowed to adhere to a polylysine-coated glass coverslip before they were fixed and labeled for GFAP and viewed as described for Figure 1.

cells from the cerebellum and none in cell suspensions prepared from the leptomeninges did so. The proportion of tetanus toxin-binding, $\mathrm{A}_{2} \mathrm{~B}^{+}{ }^{+} \mathrm{GFAP}^{+}$cells in suspensions of 14-day optic nerve was consistently greater than the proportion in suspensions of 7-day optic nerve but was always very much less than the proportion of such cells in suspensions of corpus callosum (Table II).

Developing optic nerve contains many tetanus toxinbinding, $\mathrm{A2B5}^{+}, \mathrm{GFAP}^{-}$cells, which become type 2 astrocytes in culture. One surprising result of the studies on cell suspensions of freshly dissociated tissues was that the great majority of the cells from 7- and 14-day optic nerve that bound tetanus toxin or A2B5 antibody did not contain detectable amounts of GFAP (Fig. 6). For example, it can be calculated from Table II that, while approximately $25 \%$ of the cells in 7-day optic nerve suspensions were $\mathrm{A} 2 \mathrm{~B} 5^{+}$, less than $2 \%$ of these were GFAP $^{+}$. Taken together with the findings that the proportion of astrocytes that bound tetanus toxin and A2B5 antibody was greater in cultured optic nerve than in fresh optic nerve suspensions (cf. Tables I and II), this observation raised the possibility that many of the tetanus toxin-binding, $\mathrm{A}^{\mathrm{B} 5} 5^{+}, \mathrm{GFAP}^{-}$cells started to produce 
GFAP in culture and became type 2 astrocytes. In fact, three lines of evidence supported this view.

First, when 7-day optic nerve cells were grown on polylysine-coated culture dishes and then removed from the dish and doubly labeled after $1,2,3$, and 4 days in culture, the proportion of $\mathrm{A} 2 \mathrm{~B}^{+}$cells that were $\mathrm{GFAP}^{+}$ progressively increased so that by 4 days, more than $95 \%$ of the $\mathrm{A}^{2} \mathrm{B5}^{+}$cells were GFAP ${ }^{+}$(Table III). Similarly, the proportion of tetanus toxin-binding cells that were $\mathrm{GFAP}^{+}$progressively increased (data not shown). The increase in proportion of $\mathrm{A}^{2} \mathrm{~B}^{+}$cells that were $\mathrm{GFAP}^{+}$ was not due to the selective death of $\mathrm{A}^{2} \mathrm{B5}^{+}, \mathrm{GFAP}^{-}$ cells: as can be seen in Table III, the total number of $\mathrm{A}^{2} \mathrm{~B}^{+}$cells remained relatively constant for the first 3 days of culture, while the number of $\mathrm{A}_{2} \mathrm{~B}^{+}, \mathrm{GFAP}^{+}$cells increased more than 7-fold. Moreover, when 7-day optic nerve cultures were labeled on the culture dish at various times, many of the tetanus toxin-binding and $\mathrm{A} 2 \mathrm{~B} 5^{+}$cells were seen to have adopted a process-bearing morphology as early as $12 \mathrm{hr}$ after plating, and the amount of GFAP contained in the majority of these cells seemed to increase progressively with time: while many were only weakly $\mathrm{GFAP}^{+}$after $36 \mathrm{hr}$ in culture, most were strongly $\mathrm{GFAP}^{+}$after $72 \mathrm{hr}$.
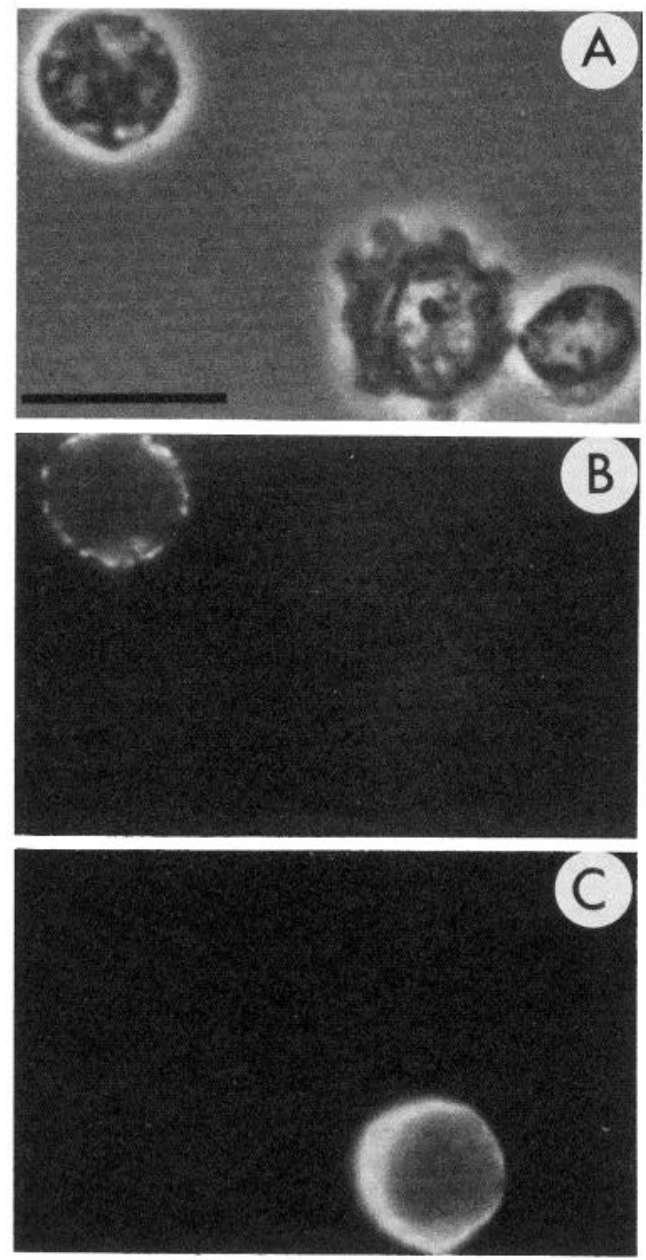

Figure 6. $\mathrm{A}^{2} \mathrm{B5}^{+}, \mathrm{GFAP}^{-}$cell in a cell suspension prepared from freshly dissected 14-day optic nerve. The cells were labeled in suspension with A2B5 antibody followed by G anti-MIg-Rd and then were treated and viewed as described for Figure 5.
TABLE III

The proportion of $\mathrm{A2B5}^{+}$cells expressing GFAP increases with time in culture

Seven-day optic nerve cells were cultured on polylysine-coated dishes $(20,000$ cells/dish), removed with trypsin/EDTA, and labeled at various times after plating. Note that the plating efficiencies in these experiments were about $25 \%$ and were similar for the $\mathrm{GFAP}^{+}$cells,

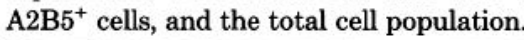

\begin{tabular}{ccccc}
\hline $\begin{array}{c}\text { Days in } \\
\text { Culture }\end{array}$ & Cell No./Dish & GFAP $^{+}$Cells & $\begin{array}{c}\text { A2B5 }{ }^{+} \text {Cells } \\
\left(\text { No./Dish }^{a}\right)\end{array}$ & $\begin{array}{c}\text { A2B5 Cells } \\
\text { Expressing GFAP } \\
(\text { No./Dish }\end{array}$ \\
\hline & & $\%$ & $\%$ & $\%$ \\
0 & & $7 \pm 3$ & $22 \pm 3$ & $5 \pm 3$ \\
1 & $5,200 \pm 2,080$ & $7 \pm 2$ & $18 \pm 4(936)$ & $13 \pm 5(122)$ \\
2 & $14,300 \pm 3,500$ & $8 \pm 4$ & $8 \pm 3(1,144)$ & $66 \pm 4(755)$ \\
3 & $34,800 \pm 3,100$ & $7 \pm 3$ & $3 \pm 2(1,044)$ & $88 \pm 6(919)$ \\
4 & $46,500 \pm 4,000$ & $4 \pm 2$ & $1 \pm 1(465)$ & $96 \pm 3(446)$ \\
\hline
\end{tabular}

${ }^{a}$ Obtained by multiplying the mean total cell number per dish by the mean percentage of $\mathrm{A} 2 \mathrm{~B} 5^{+}$cells.

${ }^{b}$ Obtained by multiplying the number of $\mathrm{A} 2 \mathrm{~B} 5^{+}$cells per dish by the mean percentage of $\mathrm{A} 2 \mathrm{~B} 5^{+}$cells expressing GFAP.

Second, when cells from 7-day optic nerve were treated with A2B5 antibody and rabbit complement and then grown on polylysine-coated culture dishes or glass coverslips, no neuron-like $\mathrm{GFAP}^{+}$cells and no tetanus toxinbinding or A2B5 ${ }^{+}$cells developed (Table IV), even after 10 days in culture; on the other hand, approximately normal numbers of type 1 astrocytes were present. Thus, in these optic nerve cultures, the development of type 2 astrocytes depended on $\mathrm{A} 2 \mathrm{~B}^{+}$cells in the initial cell suspension, and type 1 astrocytes did not give rise to type 2 astrocytes. Moreover, new A2B5 ${ }^{+}$cells did not develop from A2B5 ${ }^{-}$cells.

Third, when 7-day optic nerve cells were incubated in A2B5 antibody for $60 \mathrm{~min}$, washed thoroughly, and then cultured for 2 days on polylysine-coated coverslips before being exposed to G anti-MIg-Rd and labeled for GFAP, 65 to $75 \%$ of the type 2 astrocytes were found to have small amounts of residual A2B5 antibody on their surfaces, whereas less than $1 \%$ of the type 1 astrocytes were so labeled (not shown). In such cultures, 55 to $70 \%$ of the GFAP $^{+}$cells had a type 2 morphology. Thus, the majority of type 2 astrocytes in these cultures developed from $\mathrm{A} 2 \mathrm{~B}^{+}$cells in the initial cell suspensions.

Astrocytes seem not to switch from one type to another in culture. It has been reported that flat, fibroblast-like astrocytes can convert to process-bearing cells when exposed to dibutyryl cyclic adenosine $3^{\prime}: 5^{\prime}$-monophosphate (AMP), brain or pituitary extracts, or serum-free medium (Lim et al., 1973; Moonen et al., 1975; Lindsay et al., 1982). To determine whether this change in morphology is accompanied by a change in tetanus toxin- or A2B5 antibody-binding properties, we treated purified populations of secondary type 1 astrocytes with dibutyryl cyclic AMP ( $5 \times 10^{-4} \mathrm{M}$, added every 2 days), cholera toxin (an irreversible activator of adenylate cyclase, $1 \mu \mathrm{g} / \mathrm{ml}$ ), rat brain extract (as described by Lim et al., 1973), or bovine pituitary extract (100 to $500 \mu \mathrm{g} / \mathrm{ml}$ ) for up to 7 days in normal or serum-free medium: although many astrocytes converted to a type 2 morphology under these conditions, especially in serum-free medium, such cells did not bind tetanus toxin or A2B5 antibody. Moreover, we have 
TABLE IV

Results of treating optic nerve cells with A2B5 antibody and complement prior to culture

Approximately 40,000 7-day optic nerve cells were treated as indicated. The numbers of living cells were then determined and the cells were cultured on polylysine-coated dishes for 4 days before being removed from the dish with trypsin/EDTA, counted, and labeled in suspension.

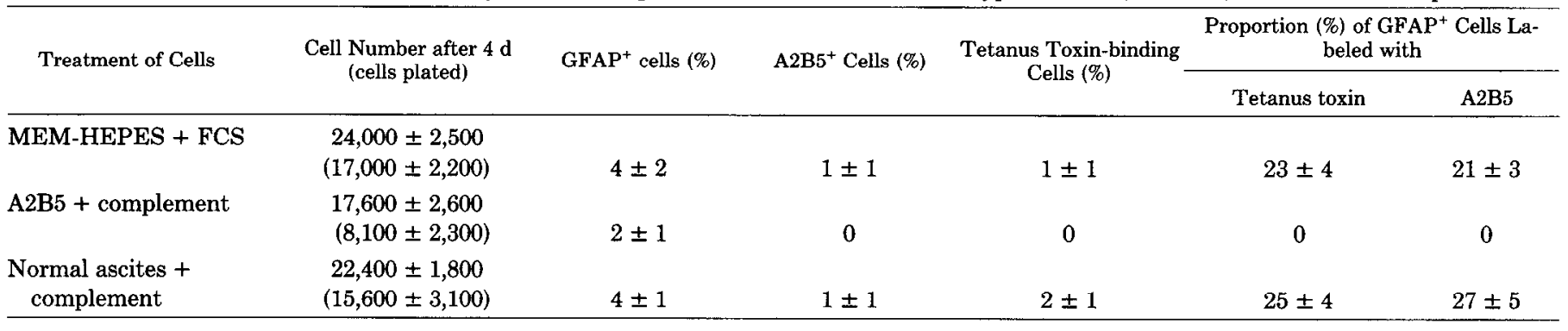

studied cultures of purified secondary astrocytes for up to 12 weeks and have not detected any cells that have spontaneously adopted a type 2 phenotype.

To determine whether type 2 astrocytes converted to type 1 astrocytes in culture, 20 cells with type 2 morphology in cultures of 7-day optic nerve were followed by time-lapse video for 2 or 3 days, beginning 1 or 2 days after plating. In no case did the cells change to a type 1 morphology. In some cases, the surrounding fibroblastlike cells divided rapidly and grew under the processbearing cells; sometime after, the latter cell often degenerated. In no case was a fibroblast-like cell seen to convert to a neuron-like cell. While most of the fibroblast-like cells divided one or more times during the period of observation, none of the neuron-like cells were observed to divide. In such cultures, 85 to $95 \%$ of the processbearing cells were $\mathrm{GFAP}^{+}$type 2 astrocytes, while most of the remaining process-bearing cells were $\mathrm{GFAP}^{-}$oligodendrocytes, identified by the binding of anti-galactocerebroside antibody (Raff et al., 1978).

Type 1 and type 2 astrocytes have different growth properties in culture. Although the time-lapse studies suggested that type 2 astrocytes divided infrequently in optic nerve cultures, it was not possible to study the proliferation of type 1 astrocytes in this way because they could not be distinguished from leptomeningeal cells, which outnumbered the type 1 astrocytes in these cultures. To circumvent this problem, 5- to 7-day optic nerve cells growing on polylysine-coated glass coverslips were exposed after 2 days in culture to $\left[{ }^{3} \mathrm{H}\right]$ thymidine for $24 \mathrm{hr}$ and then were double labeled with A2B5 and antiGFAP antibodies and processed for autoradiography. In such preparations, 40 to $50 \%$ of the type 1 astrocytes were found to incorporate $\left[{ }^{3} \mathrm{H}\right]$ thymidine, whereas $<10 \%$ of the type 2 astrocytes did so (Table V). Moreover, while the proportion of type 1 cells that incorporated $\left[{ }^{3} \mathrm{H}\right]$ thymidine was significantly increased by incubating the cells for $48 \mathrm{hr}$ in bovine pituitary extract or EGF, these reagents had no detectable influence on the incorporation of $\left[{ }^{3} \mathrm{H}\right]$ thymidine into type 2 astrocytes (Table V). While the numbers of $\mathrm{A}^{2} \mathrm{~B}^{+}$astrocytes with a fibroblast-like morphology and of A2B5- astrocytes with a neuron-like morphology were very small in these experiments, less than $20 \%$ of them incorporated $\left[{ }^{3} \mathrm{H}\right]$ thymidine, and the proportions were not significantly increased by piluilary extract or EGF (not shown). More than $80 \%$ of the GFAP $^{-}$fibroblast-like cells incorporated $\left[{ }^{3} \mathrm{H}\right]$ thymidine under all of the conditions tested (not shown).

\section{TABLE V}

The effect of growth factors on the incorporation of $\left[{ }^{3} H\right]$ thymidine by type 1 and type 2 astrocytes in culture

Seven-day optic nerve cells were cultured on polylysine-coated coverslips for 4 days. Growth factors were added for the last $48 \mathrm{hr}$ and $\left[{ }^{3} \mathrm{H}\right]$ thymidine was added for the last $24 \mathrm{hr}$ of the culture period. The cells were labeled with A2B5 and then anti-GFAP antibodies, and then they were processed for autoradiography. $\mathrm{A}^{2} \mathrm{B5}^{-}, \mathrm{GFAP}^{+}$cells with a fibroblast morphology were counted as type 1 astrocytes, while $\mathrm{A}_{2} \mathrm{~B} 5^{+}$, $\mathrm{GFAP}^{+}$cells with processes (about $35 \%$ of the $\mathrm{GFAP}^{+}$cells) were counted as type 2 astrocytes. Cells with $\geq 10$ grains over their nuclei were scored as radiolabeled.

\begin{tabular}{lcc}
\hline \multirow{2}{*}{ Treatment of Cultures } & \multicolumn{2}{c}{$\begin{array}{c}\text { Proportion of Astrocytes } \\
\text { Radiolabeled }\end{array}$} \\
\cline { 2 - 3 } & Type 1 & Type 2 \\
\hline None & $45 \pm 5$ & $6 \pm 1$ \\
Bovine pituitary extract $(100 \mu \mathrm{g} / \mathrm{ml})$ & $93 \pm 2$ & $3 \pm 2$ \\
EGF $(100 \mu \mathrm{g} / \mathrm{ml})$ & $86 \pm 3$ & $6 \pm 2$ \\
\hline
\end{tabular}

Tetanus toxin and A2B5 antibody bind to some astrocytes in cultures of normal adult white matter but not to reactive astrocytes from lesioned white matter. To determine whether adult white matter contained type 2 astrocytes (or their precursors), we studied cultures prepared from adult rat optic nerve. Whereas approximately 20,000 live cells were obtained by dissociating one pair of 7-day optic nerves, less than 1,000 viable cells were obtained from a pair of adult optic nerves. When the cells dissociated from the optic nerves of two 12- to 14-week rats were cultured on a polylysine-coated culture dish and double labeled in suspension after 7 days in culture, 5 to $10 \%$ of the cells were $\mathrm{GFAP}^{+}$and 15 to $30 \%$ of these bound tetanus toxin and A2B5 antibody. When the cells in such cultures were double labeled while still on the culture dish, most of the tetanus toxin- and A2B $5^{+}$antibody-binding astrocytes were larger and flatter than type 2 astrocytes in cultures of neonatal optic nerve and could not be distinguished morphologically from the astrocytes that did not bind these ligands (not shown).

Many more viable cells can be obtained from adult brain tissue that has been previously injured than from normal adult brain (Lindsay et al., 1982). When cells were dissociated from adult rat corpus callosum 5 or 8 days after stereotaxic lesioning and then labeled in suspension, 10 to $20 \%$ of the cells were $\mathrm{GFAP}^{+}$, but none of these were labeled by tetanus toxin or A2B5 antibody. When such cells were cultured on polylysine-coated 
coverslips or culture dishes for up to 3 weeks, no tetanus toxin-binding or $\mathrm{A} 2 \mathrm{~B}^{+}$astrocytes were found.

\section{Discussion}

We have distinguished two types of astrocytes in cultures of developing rat optic nerve on the basis of morphology, the binding of tetanus toxin and A2B5 antibody, and growth properties (Table VI). Type 1 astrocytes had a fibroblast-like morphology and did not bind detectable amounts of tetanus toxin or A2B5 antibody. Almost half of them incorporated $\left[{ }^{3} \mathrm{H}\right]$ thymidine during a 24 -hr exposure, and this proportion was approximately doubled by extracts of bovine pituitary or by EGF. Type 2 astrocytes had a neuron (or oligodendrocyte)-like morphology (being smaller and darker than type 1 cells and usually having multiple branching processes) and bound tetanus toxin and A2B5 antibody. Only a small proportion incorporated $\left[{ }^{3} \mathrm{H}\right]$ thymidine during a 24 -hr pulse, and this proportion was not increased by pituitary extract or EGF. Since bovine pituitary extract would be expected to contain both fibroblast growth factor (FGF; Gospodarowicz, 1975) and glial growth factor (GGF; Brockes et al., 1980), our results suggest that type 2 astrocytes may not respond to either. EGF, FGF, and GGF all have been reported previously to stimulate astrocyte proliferation (Brockes et al., 1980; Leutz and Schachner, 1981; Pruss et al., 1982).

Not all $\mathrm{GFAP}^{+}$astrocytes could be classified as type 1 or type 2 by the above criteria. A small proportion of astrocytes with type 1 morphology bound tetanus toxin and A2B5 antibody, while some astrocytes with type 2 morphology did not bind detectable amounts of these ligands. Moreover, some $\mathrm{GFAP}^{+}$cells in culture had an intermediate morphology. The finding of cells with such mixed phenotypes raised the possibility that type 1 and type 2 astrocytes may be interconvertible. Indeed, it has been shown that cultured astrocytes with a type 1 morphology can convert to a type 2 morphology if treated with dibutyryl cyclic AMP, brain or pituitary extracts, or serum-free medium (Lim et al., 1973; Moonen et al., 1975; Lindsay et al., 1982). However, when we treated purified

TABLE VI

Distinguishing properties of type 1 and type 2 astrocytes in culture

\begin{tabular}{lcc}
\hline \multicolumn{1}{c}{ Characteristic } & $\begin{array}{c}\text { Type } 1 \\
\text { Astrocytes }\end{array}$ & $\begin{array}{c}\text { Type } 2 \\
\text { Astrocytes }\end{array}$ \\
\hline 1. Found in & cultures of gray & cultures of white \\
& and white & matter \\
& matter & \\
2. Morphology & fibroblast-like & $\begin{array}{c}\text { neuron (or oligo- } \\
\text { dendrocyte)- } \\
\end{array}$ \\
& & like
\end{tabular}

3. Growth properties

(a) Proliferation in $10 \%$ FCS

(b) Proliferation stimulated by

(i) Pituitary extract

(ii) EGF

4. Ligand-binding properties

(a) Tetanus toxin

(b) A2B5 antibody secondary astrocytes (all having a type 1 phenotype) in these ways, although many of the cells converted to a type 2 morphology, none bound tetanus toxin or A2B5 antibody, even when maintained in these conditions for up to 1 week. Moreover, purified secondary astrocytes with a type 1 phenotype were never observed to convert spontaneously to type 2 astrocytes when they were studied for up to 12 weeks in culture; nor did we see fibroblastlike cells convert to a neuron-like morphology when cultures of optic nerve were followed for up to 3 days by time-lapse video recording. In addition, when optic nerve suspensions were treated with A2B5 antibody and complement before being cultured, many type 1 but no type 2 astrocytes were found after 3 to 7 days in culture. Similarly, type 2 astrocytes were never found in cultures of leptomeninges, even though such cultures contained substantial numbers of type 1 astrocytes, presumably derived from the underlying cerebral cortex. All of these findings suggest that type 1 astrocytes did not convert to bona fide type 2 astrocytes, at least in culture. We followed 20 process-bearing cells in 7-day optic nerve cultures ( 85 to $95 \%$ of which would be expected to be type 2 astrocytes) for 2 to 3 days by time-lapse video recording and none of them converted to a fibroblast-like morphology. Thus, we could find no evidence that astrocytes changed from one type to the other in culture, and the meaning of astrocytes with a mixed phenotype remains uncertain. However, the fact that the $\mathrm{A} 2 \mathrm{~B} 5^{+}$astrocytes with a fibroblast-like morphology and the A2B5 ${ }^{-}$astrocytes with a neuron-like morphology had the growth properties of type 2 astrocytes and were not found in cultures of leptomeninges suggests that most, if not all, of these were atypical type 2 astrocytes.

A relatively high proportion of astrocytes in cultures of white matter tracts (optic nerve and corpus callosum) had a type 2 phenotype, whereas only a small proportion of astrocytes in cultures of cerebellum (which is largely gray matter) had this phenotype, and no type 2 astrocytes were found in cultures of leptomeninges, which were always contaminated with type 1 astrocytes from the cerebral cortex. This distribution is consistent with the hypothesis that type 1 and type 2 cells in vitro correspond to protoplasmic astrocytes (which are found mainly in gray matter) and fibrous astrocytes (which are found mainly in white matter), respectively, in vivo. If so, then the fact that both type 1 and type 2 astrocytes were found side by side for many weeks in corpus callosum cultures, even after several passages, suggests that the maintenance of these phenotypic differences does not depend on the different environments in gray and white matter. Moreover, the finding that both types of astrocytes were present in cultures of optic nerve from 16- and 17-day rat embryos suggests that they may diverge as separate cell lineages early in development.

On the other hand, there are difficulties with the simple hypothesis that type 1 and type 2 astrocytes in culture correspond to protoplasmic and fibrous astrocytes, respectively, in vivo. For example, the optic nerve is composed entirely of white matter and is generally thought to contain astrocytes that are almost exclusively of the fibrous type (Vaughn and Peters, 1967). Yet cultures of developing optic nerve contained many type 1 astrocytes, 
and the great majority of $\mathrm{GFAP}^{+}$cells in fresh suspensions of both 7- and 14-day optic nerve did not bind tetanus toxin or A2B5 antibody, suggesting that they were type 1 astrocytes.

If the majority of $\mathrm{GFAP}^{+}$cells in 7- and 14-day optic nerve are type 1 astrocytes, where did all of the type 2 astrocytes come from in cultures of optic nerve? It was clear that very few developed from preexisting type 2 astrocytes by cell division, or from type 1 astrocytes by differentiation. We were surprised to find that most of the type 2 astrocytes in optic nerve cultures developed from precursor cells that bound tetanus toxin and A2B5 antibody but did not contain detectable amounts of GFAP. Moreover, comparing the results in Tables II and III, it seems apparent that many tetanus toxin-binding, $\mathrm{A}^{2} \mathrm{~B}^{+}, \mathrm{GFAP}^{-}$cells in 7-day optic nerve were induced to express GFAP by the culture conditions: whereas the great majority of tetanus toxin-binding and $\mathrm{A} 2 \mathrm{~B} 5^{+}$cells in both 7- and 14-day optic nerve suspensions were GFAP $^{-}$(Table II), after 4 days in culture, more than $95 \%$ of such cells in 7-day optic nerve had become GFAP' (Table III). Whether these tetanus toxin-binding, $\mathrm{A} 2 \mathrm{~B} 5^{+}$, GFAP $^{-}$cells also give rise to astrocytes in vivo remains to be determined. We have evidence that they may also develop into galactocerebroside-positive oligodendrocytes in culture (M. C. Raff, E. R. Abney, J. Cohen, R. Lindsay, and $M$. Noble, manuscript in preparation), which is consistent with the findings of Schachner and her colleagues that some immature oligodendrocytes are $\mathrm{A}^{+} \mathrm{B5}^{+}$(Berg and Schachner, 1982; Schnitzer and Schachner, 1982).

The finding that tissue culture conditions seem to induce tetanus toxin- and A2B5 antibody-binding cells to express GFAP raises the possibility that type 2 astrocytes are entirely a tissue culture artifact. For example, they may derive from oligodendrocyte precursor cells, which are anomalously induced to make GFAP by the culture conditions. However, two lines of evidence suggest that type 2-like astrocytes are present in normal white matter: (1) substantial numbers of tetanus toxin- and A2B5 antibody-binding, $\mathrm{GFAP}^{+}$cells were found in cell suspensions prepared from freshly dissected white matter tracts but not from freshly dissected gray matter of developing rats (Table II). (2) Immunofluorescence and immunogold labeling studies of thick and thin frozen sections have demonstrated large numbers of $\mathrm{A} 2 \mathrm{~B}^{+}{ }^{+}$astrocytes in optic nerve but not in cerebral cortex of adult rats (R. Miller and M. C. Raff, unpublished observations). Moreover, tetanus toxin- and A2B5-binding astrocytes were present in cultures of adult optic nerve; the significance of such cells, however, is unclear, because very few living cells could be obtained from adult tissues, and the morphological distinction between the astrocytes that bound tetanus toxin and A2B5 antibody and those that did not was much less clear than in cultures of neonatal optic nerve. Many more living cells could be isolated from adult corpus callosum 5 or 8 days after stereolaxic lesioning, but, surprisingly, none of the astrocytes in such preparations bound tetanus toxin or $\mathrm{A} 2 \mathrm{~B} 5$ antibody, either immediately after isolation, or after up to 3 weeks in culture. This suggests that either reactive astrocytes in white matter derive from non-tetanus toxin-binding,
A2B5- cells (perhaps because such cells respond to mitogens released at the site of injury), or that tetanus toxin-binding, $\mathrm{A} 2 \mathrm{~B} 5^{+}$astrocytes change their phenotype in response to injury. Moreover, it suggests that the rapid development of type 2 astrocytes in cultures of white matter is unlikely to be simply the result of tissue injury.

Since both tetanus toxin (Van Heyningen, 1963) and A2B5 antibody (Eisenbarth et al., 1979) have been shown to bind to polysialogangliosides, it seems likely that the differences in the binding of these ligands to type 1 and type 2 astrocytes reflect differences in the plasma membrane gangliosides of these cells. This is supported by our finding that optic nerve and corpus callosum cultures, which contained both types of astrocytes, synthesized the relevant polysialogangliosides, whereas cultures of leptomeninges, which contained only type 1 astrocytes, did not. These studies, moreover, exclude the possibility that type 2 astrocytes acquire the polysialogangliosides from neurons rather than by synthesizing them themselves.

Since cultured type 2 astrocytes bind tetanus toxin and A2B5 antibody and can look very much like neurons in the light microscope, it is clear that these ligands cannot be used on their own as neuron-specific markers in cultures of CNS tissues. On the other hand, since type 2 astrocytes seem to share as many properties with neurons as with type 1 astrocytes, one might question the validity of calling them astrocytes rather than neurons. There are at least three reasons for doing so: type 2 astrocytes contain GFAP, they do not contain neurofilament proteins, and they are found in optic nerves, which are thought not to contain neuronal cell bodies.

\section{References}

Anderton, B. H., R. Thorpe, J. Cohen, S. Selvendran, and P. Woodhams (1980) Specific neuronal localization by immunofluorescence of $10 \mathrm{~nm}$ filament polypeptides. J. Neurocytol. 9: 835-844.

Berg, G. J., and M. Schachner (1982) Electron-microscopic localization of A2B5 cell surface antigen in monolayer cultures of murine cerebellum and retina. Cell Tissue Res. 224: 637-645.

Bignami, A., L. F. Eng, D. Dahl, and C. T. Uyeda (1972) Localization of the glial fibrillary acidic protein in astrocytes by immunofluorescence. Brain Res. 43: 429-435.

Bottenstein, J. E., and G. H. Sato (1979) Growth of a rat neuroblastoma cell line in serum-free supplemented medium. Proc. Natl. Acad. Sci. U. S. A. 76: 514-517.

Brockes, J. P., K. L. Fields, and M. C. Raff (1979) Studies on cultured rat Schwann cells. I. Establishment of purified populations from cultures of peripheral nerve. Brain Res. 165: 105-118.

Brockes, J. P., G. E. Lemke, and D. R. Balzer (1980) Purification and preliminary characterization of a glial growth factor from bovine pituitary. J. Biol. Chem. 255: 8374-8377.

Cohen, A., and M. Schlesinger (1970) Absorption of guinea pig serum with agar: A method for elimination of its toxicity for murine thymus cells. Transplantation 10: 130-134.

Dimpfel, W., J. H. Neale, and E. Habermann (1975) ${ }^{125}$ I-labeled tetanus toxin as a neuronal marker in tissue cultures derived from embryonic CNS. Naunyn Schmiedesbergs Arch. Exp. Pathol. Pharmakol. 290: 329-333.

Eisenbarth, G. S., F. S. Walsh, and M. Nirenberg (1979) Monoclonal antibody to a plasma membrane antigen of neurons. Proc. Natl. Acad. Sci. U. S. A. 76: 4913-4917. 
Folch-Pi, J., M. Lees, and G. H. Sloane-Stanley (1957) A simple method for the isolation and purification of total lipids from animal tissues. J. Biol. Chem. 226: 497-509.

Gospodarowicz, D. (1975) Purification of fibroblast growth factor from bovine pituitary. J. Biol. Chem. 250: 2515-2520.

Leutz, A., and M. Schachner (1981) Epidermal growth factor stimulates DNA-synthesis of astrocytes in primary cerebellar cultures. Cell Tissue Res. 220: 393-404.

Lim, R., K. Mitsunobu, and W. K. P. Li (1973) Maturationstimulating effect of brain extract and dibutyryl cyclic AMP on dissociated embryonic brain cells in culture. Exp. Cell Res. 79: 243-246.

Lindsay, R. M., P. C. Barber, M. R. C. Sherwood, J. Zimmer, and G. Raisman (1982) Astrocyte cultures from adult rat brain. Derivation, characterization and neurotrophic properties of pure astroglial cells from corpus callosum. Brain Res. 243: $329-343$.

McCarthy, K. K., and J. de Vellis (1980) Preparation of separate astroglial and oligodendroglial cultures from rat cerebral tissue. J. Cell Biol. 85: 890-902.

McKay, R., M. C. Raff, and L. F. Reichardt (1981) Monoclonal antibodies to neural antigens. Cold Spring Harbor Rep. Neurosci. 2: 1-282.

Mirsky, R. (1982) The use of antibodies to define and study major cell types in the central and peripheral nervous system. In Neuroimmunology, J. Brockes, ed., pp. 141-181, Plenum Press, New York.

Mirsky, R., L. M. B. Wendon, P. Black, C. Stolkin, and D. Bray (1978) Tetanus toxin: A cell surface marker for neurons in culture. Brain Res 148: 251-259.

Moonen, G., Y. Cam, M. Sensenbrenner, and P. Mandel (1975) Variability of the effects of serum-free medium, dibutyryl cyclic AMP or theophylline on the morphology of cultured newborn rat astroblasts. Cell Tissue Res. 163: 365-372.

Pruss, R. (1979) Thy-1 antigen on astrocytes in long-term cultures of rat central nervous system. Nature 280: 688-690.

Pruss, R. M., P. F. Bartlett, J. Gavrilovic, R. P. Lisak, and S. Rattray (1982) Mitogens for glial cells: A comparison of the response of cultured astrocytes, oligodendrocytes and Schwann cells. Dev. Brain Res. 2: 19-35.
Raff, M. C., R. Mirsky, K. T. Fields, R. P. Iisak, S. H. Dorfman D. H. Silberberg, N. A. Gregson, S. Liebowitz, and M. Kennedy (1978) Galactocerebroside: A specific cell surface antigenic marker for oligodendrocytes in culture. Nature 274: 813-816.

Raff, M. C., K. L. Fields, S. Hakomori, R. Mirsky, R. M. Pruss, and J. Winter (1979) Cell-type-specific markers for distinguishing and studying neurons and the major classes of glial cells in culture. Brain Res. 174: 283-308.

Rosner, H., and G. Merz (1982) Uniform distribution and similar turnover rates of individual gangliosides along axons of retinal ganglion cells in the chicken. Brain Res. 236: 63-75.

Schachner, M. (1982) Immunological analysis of cellular heterogeneity in the cerebellum. In Neuroimmunology, J. Brockes, ed., pp. 215-250, Plenum Press, New York.

Schnitzer, J., and M. Schachner (1982) Cell type specificity of a neural cell surface antigen recognized by the monoclonal antibody A2B5. Cell Tissue Res 224: 625-636.

Stallcup, W. B. (1981) The NG2 antigen, a putative lineage marker: Immunofluorescent localization in primary cultures of rat brain. Dev. Biol. 83: 154-165.

Suzuki, K. (1965) 'The pattern of mammalian brain gangliosides. II. Evaluation of the extraction procedures, post-mortem changes and the effect of formalin preservation. J. Neurochem. 12: 629-638.

Svennerholm, L. (1957) Quantitative estimation of sialic acids. Biochim. Biophys. Acta 24: 605-611.

Svennerholm, L. (1963) Chromatographic separation of human brain gangliosides. J. Neurochem. 10: 613-623.

Van Heyningen, W. E. (1963) The fixation of tetanus toxin, strychnine, serotonin and other substances by gangliosides. J. Gen. Microbiol. 31: 375-387.

Vaughn, J. E., and A. Peters (1967) Electron microscopy of the early postnatal development of fibrous astrocytes. Am. J. Anat. 121: 131-152.

Wilson, S. -S., E. E. Baetge, and W. Stallcup (1981) Antisera specific for cell lines with mixed neuronal and glial properties. Dev. Biol. 83: 146-153.

Wood, J. D., and B. H. Anderton (1981) Monoclonal antibodies to mammalian neurofilaments. Biosci. Rep. 1: 263-268. 